\title{
SMN2 wt Allele
}

National Cancer Institute

\section{Source}

National Cancer Institute. SMN2 wt Allele. NCI Thesaurus. Code C127869.

Human SMN2 wild-type allele is located in the vicinity of 5q13.2 and is approximately 29 $\mathrm{kb}$ in length. This allele, which encodes survival motor neuron protein, is involved in the assembly of small nuclear ribonucleoproteins. Mutation of the gene is associated with sporadic adult-onset lower motor neuron disease (LMND) and a modified form of spinal muscular atrophy type 3 . 